\title{
Assessment of changes in the brca2 and $p 53$ genes in breast invasive ductal carcinoma in northeast Brazil
}

\author{
Eduardo AVF Ramalho', João LQ Silva-Filho ${ }^{1}$, Marina FS Cartaxo ${ }^{1}$, Carmelita BL Cavalcanti ${ }^{1}$, Moacyr JBM Rêgo ${ }^{1}$, \\ Maria BM Oliveira ${ }^{2}$ and Eduardo IC Beltrão $0^{1,2,3^{*}}$
}

\begin{abstract}
Background: BRCA protein interacts with at least 13 different proteins that have been implicated with cancer susceptibility and loss of BRCA function is correlated to sensitivity to DNA crosslinking agents in preclinical models.

Results: BRCA2 methylation frequency was 44\%, p53 Pro22 allele frequency was 32\% and heterozygous frequency of Arg/Pro72 genotype was 60\% which could be associated as risk factor for metastasis ( $p=0.046 \mathrm{OR}=4.190$ ). Regarding to polymorphism of codon 249 the frequency of Arg249 allele presented 82\% which was considered not statistically significant.

Conclusions: There was not statistical significance to BRCA2 promoter methylation with any parameters chosen. However, our findings suggest that patients who present heterozygous genotype at codon 72 of p53 gene may have a major susceptibility to any type of metastasis and this could serve as potential auxiliary biomarker for poor prognosis.
\end{abstract}

Keywords: Breast cancer, Epigenetics, Metastasis, Methylation, Polymorphism

\section{Background}

It is well known that BRCA2 gene encode functionally related proteins that play critical roles in DNA doublestrand breaks repair [1-3]. BRCA protein interacts with at least 13 different proteins that have been implicated with cancer susceptibility, suggesting that BRCA gene works as an essential signaling network dedicated to genome integrity [4-8]. Loss of BRCA function results in development of chromosomal instability and this 'BRCAness' (loss of BRCA function or BRCA-null) phenotype correlated to sensitivity to DNA cross-linking agents in preclinical models [9-11].

In contrast to non-coding regions of the genome where most CpGs are methylated, CpG islands in 5' cis-regulatory regions of genes are usually unmethylated. Methylation of these $\mathrm{CpG}$ islands during the

\footnotetext{
* Correspondence: ebeltrao@hotmail.com

'Keizo Asami Immunopathology Laboratory, Federal University of

Pernambuco, Recife, Pernambuco, Brazil

${ }^{2}$ Biochemistry Department, Federal University of Pernambuco, Recife,

Pernambuco, Brazil

Full list of author information is available at the end of the article
}

development or disease processes is associated with post-translational histone modifications that lead to a locally condensed inactive chromatin structure and gene silencing $[12,13]$. During tumorigenesis, there is a progressive loss of global DNA methylation and at the same time regional hypermethylation [14]. Tumor-specific hypermethylation of CpG islands in $5^{\prime}$ promoters can inactivate genes for DNA repair, cell cycle control and other mechanisms that prevent neoplastic transformation in a normal cell [15]. Epigenetic abnormalities do not only occur as secondary changes at all stages of tumor evolution, but can also act as initiating events [16].

As a diagnostic technique methylation-specific PCR (MSP) could be highlighted [17]. The precise mapping of DNA methylation patterns in CpG islands has become essential for understanding many biological processes such as gene regulation, $\mathrm{X}$ chromosome inactivation and silencing of tumor suppressor genes. The MSP technique can quickly assess the methylation pattern of virtually any promoter region which contains therein one or more CpG islands. MSP is sensitive to $0.1 \%$ methylated alleles of a 
particular CpG island and can be also performed in formalin-fixed paraffin-embedded tissues the most common sample presentation for diagnosis. Early detection of aberrant methylation in carcinogenesis related genes may be essential for diagnosis, prognosis and/or detection of metastatic potential [17].

DNA methylation is an important epigenetic mechanism that occurs in $\mathrm{CpG}$ sites and is directly involved in gene regulation [18-22]. In human cancer, such nongenetic modification which can be heritable consists in a powerful mechanism responsible for the inhibition of different genes, including tumor suppressor genes [23].

The tumor suppressor gene p53 plays a major role in cell cycle control, apoptosis and maintenance of DNA integrity. Due to its importance in cell cycle control and integrity, it was nicknamed "genome guardian" [24,25]. Mutations and genetic polymorphisms may alter the function of p53 proteins leading to imbalances in the major gene functions [26,27].

Among TP53 gene polymorphisms, the most studied is the $G$ to $C$ transversion in exon 4 at codon 72 (rs1042522), which encodes two distinct functional allelic forms, arginine (Arg) and proline (Pro) and results in three distinct genotypes, Arg / Arg, Pro / Pro and Arg / Pro, each one encoding different p53 isoforms [28].

Another hotspot in p53 gene is frequently founded at exon 7 which occurs a $G$ to $T$ transversion at the third position of codon 249 (rs28934571) of the coding sequence of the gene which results in the substitution of Serine for Arginine [29]. This study analyzed BRCA2 promoter region methylation pattern and p53 Single Nucleotide Polymorphisms (SNP) correlating with clinicpathological parameters such as age, tumor size, lymph node involvement and metastasis of patients from Recife, Pernambuco, Northeast Brazil.

\section{Results}

\section{BRCA2 MS-PCR}

DNA samples were extracted, quantified and subsequently amplified by PCR using the housekeeping gene $\beta$-globin (data not shown) from fifty biopsies from patients diagnosed with IDC and five healthy controls were subjected to MS-PCR amplification. The frequency of
BRCA2 promoter methylation in all IDC patients corresponded to $44 \%$ (22 of 50) (Figure 1).

\section{p53 PCR-RFLP}

Amplified products of exon 4 and exon 7 were 353 bp and $177 \mathrm{bp}$, respectively (Figure 2a and b). Detection of p53 codon 72 polymorphisms by PCR-RFLP was successfully conducted in all cases and controls. Arginine allele was cleaved by Bst UI yielding two smaller fragments (214pb and 139pb). On the other hand, Proline allele resulted in a single band of $353 \mathrm{bp}$. Heterozygous samples showed a three bands genotype (353, 214 and $139 \mathrm{pb}$ ) as shown in Figure 3a. PCR-RFLP of p53 codon 249 was successfully conducted in all cases and controls. Arg249 digestion presented four fragments (92, 62, 23 and 12pb). Serine249 genotype showed loss of restriction site for HaeIII yielding an uncleaved fragment of 154 bp besides 92, 62, 23 and 12 bp fragments (Figure $3 \mathrm{a}$ and $\mathrm{b}$ ).

The genotypic frequency of Proline72 allele was 32\% (16 of 50). Unlike Arg/Pro72 genotype which presented a frequency of $60 \%$ (30 of 50), Arg72 frequency was only $8 \%$ ( 4 of 50 ). In relation to allelic frequency, our results revealed a predominance of Pro72 allele with 62\% while for Arg72 allele the frequency was 38\%. Comparison between p53 codon 72 genotype and clinical pathologic data is summarized in Tables 1 and 2. p53 codon 249 analysis has shown no statistic significance with any parameters chosen in this study and its genotyping frequency of Serine249 allele was 18\% (9 of 50) while Arg249 allele was $82 \%$ (41 of 50 ). We also tried to achieve some association between BCRA2 methylation status and p53 polymorphisms of IDC patients analyzing each patient who presented amplified methylated alleles and correlate it with any possible p53 gene isoform expressed. However, nothing significant was founded $(p>0.05)$.

When analyzing methylation status and p53 hotspots, among all patients who presented BRCA2 promoter methylation, 68.2\% expressed Arg / Pro 72 genotype and Pro / Pro genotype frequency was $31.8 \%$. There was no Arg / Arg homozygote genotype frequency in patients who had BRCA2 promoter methylation. Concerning codon 249 polymorphisms, the frequency of Arginine 249 was $81.8 \%$ for methylation BRCA2 patients, while for Serine 249 was

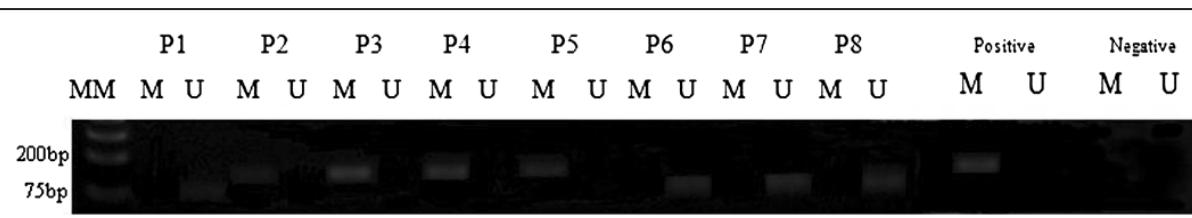

Figure 1 1\% Agarose gel showing methylation status of promoter BRCA2 gene in IDC patients. MM: Molecular Marker (Fermentas GeneRuler 1 kb Plus); P: IDC Patients (1-8); M: Methylated alleles (139 bp); U: Unmethylated alleles (79 bp). Positive control: DNA from human blood treated by Sssl Methylase; Negative control: Nucelase free water (blank control). 


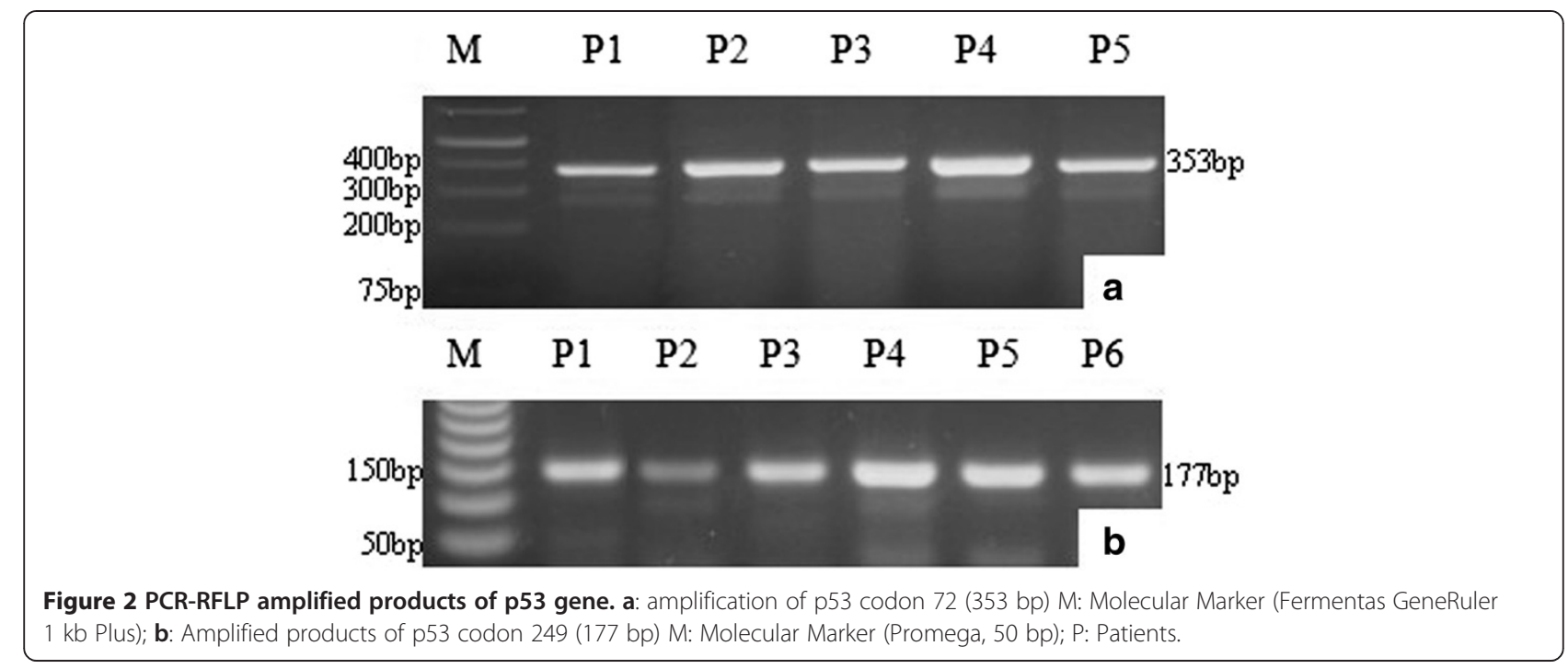

18.2\%. However no correlation between methylation status/polymorphism and clinical-pathological data could be established with any parameter chosen in this study.

\section{Discussion}

In this study, we aimed to understand human TP53 codon 72 polymorphism associated with IDC development since this common substitution of one base pair at codon 72 of the gene changes the biochemical and functional properties of the protein. The frequency, time and spectrum of p53 gene mutation may be useful to provide clues to the etiology and pathogenesis of human cancer. Several studies proposed the role of codon 72 polymorphism as a risk factor for different types of cancers such as stomach, lung and bladder [30]. Among three codon 72 genotypes, Arginine is more susceptible to degradation by human papillomavirus (HPV) E6 type-18 protein and suppresses cellular transformation more effectively than Pro72. On the other hand Arg72 is more efficient than Pro72 to induce apoptosis [27]. Additionally, variants of the TP53 gene seem to confer differential responses to chemotherapy [31]. The Arg / Arg genotype was reported to be associated to a higher response rates and survival in patients with breast [32,33], lung [34] or head and neck cancer [35].

Our results showed a predominance of the proline allele $(62 \%)$ and the heterozygous Arg / Pro represents the most common genotype (60\%) among this research subjects. These findings are not in line with a recent study of TP53 polymorphism among 96 individuals [36] from a Brazilian population where was found a high prevalence of Arginine allele (68\%) showing a contrast to our

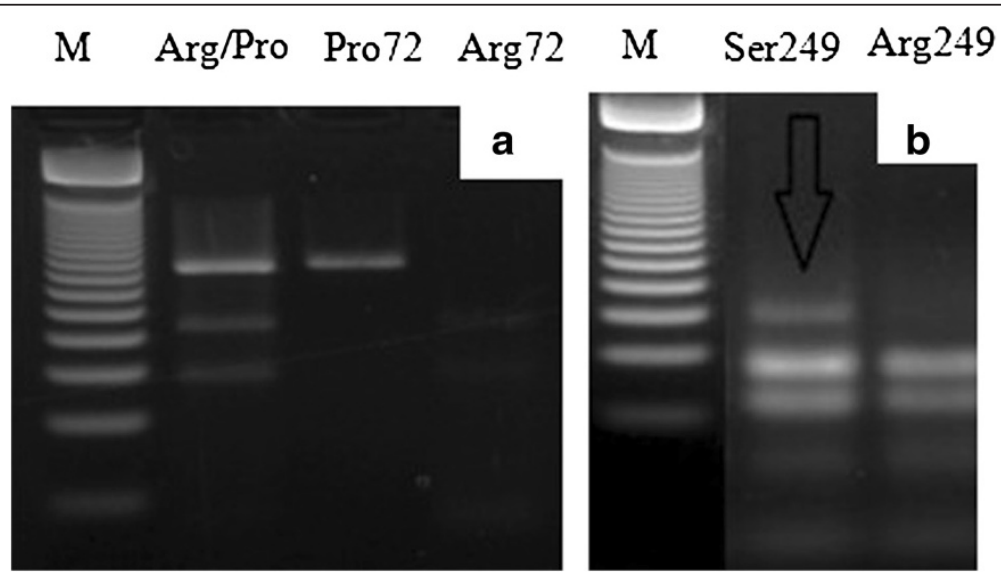

Figure 3 PCR-RFLP analysis of p53 gene (Arg/Pro genotype). a: p53 codon 72. M: Molecular weight marker (Promega 50 bp). Heterozygous genotype Arg/Pro; Proline genotype showing lack of restriction site (353 pb band); Arginine genotype cleaved by the enzyme resulting in two fragments (214 and 139 bp). b: p53 codon 249. M: Molecular weight marker (Promega 50 bp); Arrow indicates the fragment corresponding to 249Ser genotype (154 pb) not cleaved by Haell; Enzyme digestion fragments showing the Arg249 genotype with 92 and 62 bp. 
Table 1 Homozygote Pro/Pro72 versus Heterozygote Arg/Pro72

\begin{tabular}{|c|c|c|c|c|c|c|}
\hline \multirow[t]{3}{*}{ Parameter } & \multicolumn{2}{|c|}{ Codon 72 polymorphism } & \multirow[t]{3}{*}{$p$} & \multirow[t]{3}{*}{ RR (IC95\%) } & \multirow[t]{3}{*}{ OR (IC95\%) } & \multirow[t]{3}{*}{$x^{2}$} \\
\hline & Pro/Pro72 & Arg/Pro72 & & & & \\
\hline & $(n=15)$ & $(n=30)$ & & & & \\
\hline \multicolumn{7}{|c|}{ Age (in years) } \\
\hline $30-50$ & 6 & 13 & 0.903 & 0.9474 (0.3965 to 2.263) & $0.9231(0.2548$ to 3.344$)$ & 0.0148 \\
\hline$>51$ & 8 & 16 & & & & \\
\hline \multicolumn{7}{|c|}{ Tumor size $(\mathrm{cm})$} \\
\hline$<5$ & 11 & 26 & 0.2701 & $0.5946(0.2536$ to 1.394$)$ & 0.4231 (0.08932 to 2.004) & 1.216 \\
\hline$>5$ & 4 & 4 & & & & \\
\hline \multicolumn{7}{|c|}{ Lymph node involvement } \\
\hline Negative & 7 & 10 & 0.3845 & 1.441 (0.6372 to 3.260$)$ & 1.750 (0.4928 to 6.215$)$ & 0.7563 \\
\hline Positive & 8 & 20 & & & & \\
\hline \multicolumn{7}{|l|}{ Metastasis } \\
\hline Negative & 11 & 14 & 0.046 & 2.787 (0.9011 to 8.617$)$ & 4.190 (0.9686 to 18.13$)$ & 3.960 \\
\hline Positive & 3 & 16 & & & & \\
\hline
\end{tabular}

Arg (Arginine); Pro (Proline).

study where Arginine allele frequency was 38\% (19 of 50). However, we did not find an association between p53 genotype and breast cancer development.

Hence, our findings showed a low prevalence of homozygosity for Arginine 72 alleles in patients with breast cancer in opposition to results found in cases from Greece [37], Turkey [38] and in Southern Brazil [26]. These findings may be result of a high heterogeneity in Northeast Brazilian population mainly as consequence of the colonization history (Europeans, Africans and Brazilian Indians).

In most cases, when trying to establish some association with genotypic or allele polymorphism the disease presents an unfavorable prognosis for the patient.
Although our results demonstrate a $60 \%$ genotypic frequency related to Arg / Pro72, no association with IDC development could be established. However, these data suggest a relative association between heterozygous Arg / Pro genotype and metastasis $(p=0.046 \mathrm{OR}=4.190)$ which may be related by increasing the chance to develop a future metastasis since this feature was observed in patients with a more aggressive phenotype, being more genetically unstable and consequently more susceptible for metastasis. These findings could be useful in the near future where we may be able to promote prevention campaigns directed to the people's genotype since the Pro72 genotype presented itself as more stable against any type of metastasis $(p=0.004 \mathrm{OR}=0.0338)$.

Table 2 Homozygote Arg/arg72 versus Homozygote Pro/pro72

\begin{tabular}{|c|c|c|c|c|c|c|}
\hline \multirow[t]{2}{*}{ Parameter } & \multicolumn{2}{|c|}{ Codon 72 Polymorphism } & \multirow[t]{2}{*}{$p$} & \multirow[t]{2}{*}{ RR (IC95\%) } & \multirow[t]{2}{*}{ OR (IC95\%) } & \multirow[t]{2}{*}{$x^{2}$} \\
\hline & $\begin{array}{c}\text { Arg/Arg72 } \\
(n=4)\end{array}$ & $\begin{array}{c}\text { Pro/Pro72 } \\
(n=15)\end{array}$ & & & & \\
\hline \multicolumn{7}{|c|}{ Age (in years) } \\
\hline $30-50$ & 2 & 6 & 0.7998 & $1.25(0.2225$ to 7.022$)$ & $1.333(0.1436$ to 12.38$)$ & 0.0642 \\
\hline$>51$ & 2 & 8 & & & & \\
\hline \multicolumn{7}{|c|}{ Tumor size $(\mathrm{cm})$} \\
\hline$<5$ & 2 & 11 & 0.3724 & 0.4615 (0.08389 to 2.539$)$ & $0.3636(0.03756$ to 3.520$)$ & 0.7957 \\
\hline$>5$ & 2 & 4 & & & & \\
\hline \multicolumn{7}{|c|}{ Lymph node involvement } \\
\hline Negative & 0 & 7 & 0.0856 & 0 & 0.125 (0.005770 to 2.748$)$ & 2.956 \\
\hline Positive & 4 & 8 & & & & \\
\hline \multicolumn{7}{|l|}{ Metastasis } \\
\hline Negative & 0 & 11 & 0.004 & 0 & $\mathbf{0 . 0 3 3 8}(0.0014$ to 0.7955$)$ & 8.082 \\
\hline Positive & 4 & 3 & & & & \\
\hline
\end{tabular}

Arg (Arginine); Pro (Proline). 
Opposite results were found regarding the involvement of Arg / Pro heterozygous variant and increased breast cancer risk in North Indian population [26]. Another study reported that Proline homozygosity at p53 codon 72 is associated with decreased breast cancer risk in Arab women [39].

So far, there are no results that can support any proposed theory about the role of codon 72 polymorphisms as risk factor for breast cancer, this may be associated to a large number of studies showing conflicting results. Our analysis concerning exon 7 showed a frequency of 18\% for Ser 249 allele and 82\% for Arg249 of breast cancer patients, which was considered not statistically significant. Both genotypes related to codon 249 polymorphisms showed no significance when crossed with any parameters chosen for this study. Our results are in accordance with studies in Indian population showing that codon 249 polymorphisms had no association as risk factor for breast cancer [25].

There are no doubts about the importance of methylation pattern in BRCA2 promoter region in breast and ovarian carcinoma. Our findings demonstrate a frequency of $44 \%$ methylation in promoter region of BRCA2. Comparison between BRCA2 methylation status and p53 polymorphisms, Arg249 was the most prevalent (81.8\%) genotype among patients who presented promoter methylation in BRCA2. Therefore, no association between methylation status and p53 polymorphisms could be established.

BRCA2 and p53 genes being extensively studied worldwide, there are some medical centers performing genetic tests for evaluation of germline mutations in BRCA2 for genetic counseling, but little is known about the epigenetic profile if would be a useful auxiliary tool in early diagnosis of breast and ovarian cancer. Further studies will be necessary to establish methylation status of tumor suppressor genes as early diagnosis tool in cancer development. In this sense, our findings suggest that the northeast Brazilian patients who present heterozygous genotype Arg/Pro at codon 72 of p53 gene may have a major susceptibility to develop any type of future metastasis which could be indicate as potential auxiliary biomarker for poor IDC prognosis.

\section{Conclusion}

Our findings suggest that patients who present heterozygous genotype at codon 72 of p53 gene may have a major susceptibility to any type of metastasis and this could serve as potential auxiliary biomarker for poor prognosis.

\section{Methods \\ Samples}

Fifty formalin-fixed and paraffin-embedded biopsies diagnosed as invasive ductal carcinoma (IDC) and five normal tissues (from reducing mastoplasty) were obtained from Anatomy Pathology Service of Hospital das Clínicas at Federal University of Pernambuco (UFPE), Brazil. This study was approved by the Health Science Center Bioethical Board of UFPE (SISNEP FR - 272931, CEP/CCS/UFPE No 195/09). Exclusion criteria included patients under 30 year-old and samples with different types of carcinoma besides IDC. Clinical and pathological parameters such as: age, tumor size, lymph node invasion and metastasis were evaluated.

\section{DNA isolation}

After repeated attempts to standardize the whole method, was stipulated that ten sections $(10 \times 2 \mu \mathrm{m})$ of each FFPE biopsy would be necessary to be placed into an Eppendorf tube $(2 \mathrm{~mL})$ for deparaffinization. Xylene $(1 \mathrm{~mL})$ was added, mixed (40-50 seconds) and samples incubated at $25^{\circ} \mathrm{C}$ for $30 \mathrm{~min}$ (vortexed every $10 \mathrm{~min}$ ). Samples were centrifuged at 14,000 rpm for $3 \mathrm{~min}$ and xylene was discarded. Ethanol $(1 \mathrm{~mL})$ was added and mixed by inversion followed by centrifugation at 14,000 rpm for $3 \mathrm{~min}$. Ethanol was removed and ethanol/centrifuge process was repeated. The supernatant was discarded and the samples were dried using a vacuum centrifuge. After drying, samples received $400 \mu \mathrm{L}$ of cell lysis buffer (0.5 M EDTA, $5 \mathrm{M} \mathrm{NaCl}, 1 \mathrm{M}$ Tris), $36 \mu \mathrm{L}$ of SDS (20x), $24 \mu \mathrm{L}$ of Proteinase $\mathrm{K}(20 \mathrm{mg} / \mathrm{mL})$ and $20 \mu \mathrm{L}$ of MilliQ water. Samples were incubated at $65^{\circ} \mathrm{C}$ in a water bath for $18 \mathrm{~h}$. After that $420 \mu \mathrm{L}$ of $5 \mathrm{M} \mathrm{NaCl}$ solution was added and samples were centrifuged at 14,000 rpm for $20 \mathrm{~min}$. Supernatant was transferred to an Eppendorf tube, and $800 \mu \mathrm{L}$ of cold isopropyl alcohol was added followed by centrifugation at $14,000 \mathrm{rpm}$ for $20 \mathrm{~min}$. Supernatant was discarded and ethanol $(500 \mu \mathrm{L})$ was added and briefly vortexed. Samples were centrifuged at 14,000 rpm for $15 \mathrm{~min}$ and the supernatant was discarded. DNA was vacuum centrifuge dried, dissolved in $100 \mu \mathrm{L}$ of TE buffer and stored at $-20^{\circ} \mathrm{C}$ until use. DNA quantification was performed by Nanodrop 2000 Spectrophotometer (Thermo Scientific, USA) and the amount of DNA was approximately $50 \mathrm{ng} / \mu \mathrm{l}$ for each sample.

\section{Identification of $\mathrm{CpG}$ islands in the promoter region of BRCA2 gene}

Methyl Primer Express ${ }^{\ominus}$ software (Applied Biosystems) was used in order to identify CpG islands and design primers for MSP technique. Methylation specific primers were designed to the promoter region in exon 1 in the $5^{\prime}$ untranslated region of the BRCA2 gene. Primers for amplification were as follows: BRCA2 Methylated Forward (5' - AAATTAGGCGGTAGAGGC-3'), and Reverse (5' - ATAAACTAACAAAAACCGCG-3'), BRCA2 Unmethylated Forward (5' - TTGAAATTAGGTGGTAG AGGT-3') and Reverse (5' - AAATAAACTAACAAAAA CCACAC-3'). 


\section{Bisulfite treatment}

Bisulfite treatment of genomic DNA $(2 \mu \mathrm{g})$ was carried out using Epitect Bissulfite Kit (QIAGEN) following manufacturer's instructions.

\section{BRCA2 Methylation analysis (MSP)}

All MSP reactions were performed using GoTaq $^{\circledR}$ Green Master Mix (Promega) following the manufacturer's instructions. It was used $0.4 \mu \mathrm{M}$ of each primer and $50 \mathrm{ng}$ of DNA template (final volume reaction was $12.5 \mu \mathrm{L}$ ). Amplification conditions were: BRCA2 methylated allele (hot start at $94^{\circ} \mathrm{C}$ for $5 \mathrm{~min}$ followed by 40 cycles of $94^{\circ} \mathrm{C}$ for $50 \mathrm{sec}, 51^{\circ} \mathrm{C}$ for $40 \mathrm{sec}$ and $72^{\circ} \mathrm{C}$ for $45 \mathrm{sec}$ ); BRCA2 unmethylated alleles (hot start at $94^{\circ} \mathrm{C}$ for 5 min followed by 35 cycles of $94^{\circ} \mathrm{C}$ for $45 \mathrm{sec}, 50^{\circ} \mathrm{C}$ for $40 \mathrm{sec}$ and $72^{\circ} \mathrm{C}$ for $45 \mathrm{sec}$ ). In all MSP reactions was performed a $5 \mathrm{~min}$ final extension. Reaction products were separated by electrophoresis on 1\% agarose/ Sodium borate gel at $100 \mathrm{~V}$ for 90 minutes, stained with ethidium bromide $(0.5 \mu \mathrm{g} / \mathrm{mL})$ and photodocumentated in LPIX (Loccus Biotechnology). For MSP technique was expected a 139 bp amplicons to methylated alleles and $79 \mathrm{bp}$ for unmethylated alleles. As a control for the methylated-specific primers, SssI methylasetreated DNA was used to generate a full methylated DNA at all of the CpG sites. Water was used as template in negative control.

\section{p53 genotyping}

All PCR reactions were performed using GoTaq $^{\circledR}$ Green Master Mix (Promega) following the manufacturer's instructions. Primers were obtained according to IARC TP53 Database where exon 4 was amplified using $0.4 \mu \mathrm{M}$ of each primer: forward (5'-TGCTCTTTTCA CCCATCTAC-3') and reverse (5'-ATACGGCCAGG CATTGAAGT-3') and for exon 7 it was used $0.4 \mu \mathrm{M}$ of each primer: forward (5'-AGGCGCACTGGCCTCAT CTT- $3^{\prime}$ ) and reverse (5'-TGTGCAGGGTGGCAAGTG GC-3'). In both reactions it was used $50 \mathrm{ng}$ of DNA template (final reaction volume $=12.5 \mu \mathrm{L}$ ). The expected amplified products were $353 \mathrm{bp}$ for exon 4 and $177 \mathrm{bp}$ for the exon 7. Amplicons were evaluated on 1\% agarose gel electrophoresis and stained with ethidium bromide $(0.5 \mu \mathrm{g} / \mathrm{mL})$. Amplification conditions were hot start at $94^{\circ} \mathrm{C}$ for $2 \mathrm{~min}$ followed by 40 cycles of $94^{\circ} \mathrm{C}$ for $1 \mathrm{~min}$, $60^{\circ} \mathrm{C}$ for $45 \mathrm{sec}$ and $72^{\circ} \mathrm{C}$ for $45 \mathrm{sec}$ with a final extension at $72^{\circ} \mathrm{C}$ for $5 \mathrm{~min}$. As negative control, a sample without DNA template was also included in the PCR reaction to ensure that no contamination was introduced.

PCR data was confirmed by performing RFLP analysis. It was used $0.5 \mu \mathrm{L}$ (10 units) of enzyme Bst $\mathrm{UI}$ (Biolabs), $2 \mu \mathrm{L}$ of $1 \mathrm{x}$ buffer, $15 \mu \mathrm{L}$ of DNA fragment and $2.5 \mu \mathrm{L}$ of nuclease free water (total volume of $20 \mu \mathrm{L}$ ). Reactions were carried out for $2 \mathrm{~h}$ at $60^{\circ} \mathrm{C}$ in the thermocycler.
Restriction products were electrophoresed on $2 \%$ agarose gel at $90 \mathrm{~V}$ for 120 minutes and stained with ethidium bromide $(0.5 \mu \mathrm{g} / \mathrm{mL})$. The $177 \mathrm{pb}$ fragment derived from exon 7 of the p53 gene was digested using $0.5 \mu \mathrm{L}$ (5 units) of the HaeIII (Biolabs), $2 \mu \mathrm{L}$ of 10x buffer, $15 \mu \mathrm{L}$ of DNA fragment and $2.5 \mu \mathrm{L}$ of nuclease free water (total volume of $20 \mu \mathrm{L}$ ). Reactions were developed for $2 \mathrm{~h}$ at $37^{\circ} \mathrm{C}$ followed for $20 \mathrm{~min}$ at $80^{\circ} \mathrm{C}$ for enzyme activity inhibition. Resulting fragments were evaluated on a $2 \%$ agarose gel at $90 \mathrm{~V}$ for 120 minutes and stained with ethidium bromide $(0.5 \mu \mathrm{g} / \mathrm{mL})$. The mutation studied on p53 codon 72 was rs. 1042522 and on codon 249 of p53 was AGG $\rightarrow$ AGT a substitution in the third position of the codon changing an arginine for a serine.

\section{Statistical analysis}

All Statistical analysis was performed using GraphPad Prism version 5. The contingency analysis was used to compare the associations of categorical variables and $p$ values were derived from the method of chi-square. The association between TP53 codon 72 polymorphism and clinic parameters was estimated by calculating the odds ratio (OR) and its 95\% confidence interval (CI). OR estimate the chance of an event occurring in one group compared to another group. $p<0.05$ was considered statistically significant.

\section{Competing interests}

The authors declare that they have no competing interests.

\section{Authors' contributions}

EAVFR carried out the selection of samples and molecular genetic studies, participated in the DNA isolation, primers design, bissulfate treatment, BRCA2 methylation analysis, p53 genotyping; JLQS-F participated in the BRCA2 methylation analysis and p53 genotyping; MFSC participeted in the DNA isolation, primers design, bissulfate treatment, BRCA2 methylation analysis, p53 genotyping; CBLC participated in the DNA isolation and bissulfate treatment; MJBMR participated in the BRCA2 methylation analysis, p53 genotyping and statistical analysis; MBMO and EICB, equally participated in the experimental design, paper discussion and review. All authors read and approved the final manuscript.

\section{Acknowledgements}

This research was supported by Coordenação de Aperfeiçoamento de Pessoal de Nível Superior (CAPES); Conselho Nacional de Desenvolvimento Científico e Tecnológico (CNPq) and Fundação de Amparo à Ciência e Tecnologia do Estado de Pernambuco (FACEPE).

\section{Author details}

${ }^{1}$ Keizo Asami Immunopathology Laboratory, Federal University of Pernambuco, Recife, Pernambuco, Brazil. 'Biochemistry Department, Federal University of Pernambuco, Recife, Pernambuco, Brazil. 'aboratório de Imunopatologia Keizo Asami (LIKA), Universidade Federal de Pernambuco (UFPE), Av. Prof. Moraes Rego, s/n, Cidade Universitária, Recife PE 50670-901, Brazil.

Received: 22 March 2013 Accepted: 24 October 2013

Published: 26 March 2014

\section{References}

1. Venkitaraman AR: Linking the cellular functions of BRCA genes to cancer pathogenesis and treatment. Annu Rev Pathol 2009, 4:461-487.

2. Tutt A, Ashworth A: The relationship between the roles of BRCA genes in DNA repair and cancer predisposition. Trends Mol Med 2002, 8:571-576. 
3. Karran P: DNA double strand break repair in mammalian cells. Curr Opin Gen Dev 2000, 10:144-150.

4. Solyom S: Breast cancer-associated Abraxas mutation disrupts nuclear localization and DNA damage response functions. Sci Transl Med 2012, 4:122-123.

5. Erkko H, Xia B, Nikkilä J, Schleutker J, Syrjäkoski K, Mannermaa A, Kallioniemi A, Pylkäs K, Karppinen SM, Rapakko K, Miron A, Sheng Q, Li G, Mattila H, Bell DW, Haber DA, Grip M, Reiman M, Jukkola-Vuorinen A, Mustonen A, Kere J, Aaltonen LA, Kosma VM, Kataja V, Soini Y, Drapkin Rl, Livingston DM, Winqvist R: A recurrent mutation in PALB2 in Finnish cancer families. Nature 2007, 446:316-319.

6. Rahman N, Seal S, Thompson D, Kelly P, Renwick A, Elliott A, Reid S, Spanova K, Barfoot R, Chagtai T, Jayatilake H, McGuffog L, Hanks S, Evans DG, Eccles D, Breast Cancer Susceptibility Collaboration (UK), Easton DF, Stratton MR: PALB2, which encodes a BRCA2-interacting protein, is a breast cancer susceptibility gene. Nat Genet 2007, 39:165-167.

7. Seal S, Thompson D, Renwick D, Elliott A, Kelly P, Barfoot R, Chagtai T, Jayatilake H, Ahmed M, Spanova K, North B, Mcguffog L, Evans DG, Eccles D, The Breast Cancer Susceptibility Collaboration (UK), Easton DF, Stratton MR, Rahman N: Truncating mutations in the Fanconi anemia J gene BRIP1 are lowpenetrance breast cancer susceptibility alleles. Nat Genet 2006, 38:1239-1241.

8. Nikkilä J, Coleman KA, Morrissey D, Pylkäs K, Erkko H, Messick TE, Karppinen SM, Amelina A, Winqvist R, Greenberg RA: Familial breast cancer screening reveals an alteration in the RAP80 UIM domain that impairs DNA damage response function. Oncogene 2009, 28:1843-1852.

9. Tassone P, Di Martino MT, Ventura M: Loss of BRCA1 function increases the antitumor activity of cisplatin against human breast cancer xenografts in vivo. Cancer Biol 2012, 8:648-653.

10. Powell SN, Kachnic LA: Therapeutic exploitation of tumor cell defects in homologous recombination. Anticancer Agents Med Chem 2008, 8:448-460.

11. Chirnomas D, Taniguchi T, De la Vega M: Chemosensitization to cisplatin by inhibitors of the Fanconi anemia/BRCA pathway. Mol Cancer Ther 2006, 5:952-961.

12. Nygren AOH, Najim A: Methylation-Specific MLPA (MS-MLPA): simultaneous detection of $\mathrm{CpG}$ methylation and copy number changes of up to 40 sequences. Nucleic Acids Res 2005, 33:124-128.

13. Esteller M: Aberrant DNA Methylation as a cancer-inducing mechanism. An Rev Pharmacol Toxicol 2005, 45:629-656.

14. Momparler RL: Cancer epigenetics. Oncogene 2003, 22(42):6479-6483.

15. Bird AP: CpG-rich islands and the function of DNA methylation. Nature 1986, 321:209-213.

16. Larsen F, Gundersen G, Prydz H: Choice of enzymes for mapping based on CpG islands in the human genome. Genet Anal Tech Appl 1992 9:80-85.

17. Herman JG, Graff JR, Myöhänen S, Nelkin BD, Baylin SB: Methylationspecific PCR: a novel PCR assay for methylation status of $\mathrm{CpG}$ islands. Proc Natl Acad Sci 1996, 93:9821-9826.

18. Gomez-Lazaro M, Fernandez-Gomez FJ, Jordán JJ: p53: twenty five years understanding the mechanism of genome protection. J Physiol Biochem 2004, 60(4):287-307.

19. Lane DP: Cancer. p53, guardian of the genome. Nature 2005, 358(6381):15-16.

20. Orsted DD, Bojesen SE, Tybjaerg-Hansen A, Nordestgaard BG: Tumor supressor p53 Arg72Pro polymorphism and longevity, cancer survival, and risk of cancer in the general population. J Exp Med 2007, 204:1295-1301.

21. Shu K, Li B, Wu LX: The p53 network: p53 and its downstream genes. Colloids Surf. B Biointerfaces 2007, 55:10-18.

22. Petitjean A, Mathe E, Kato S, Ishioka C, Tavtigian SV, Hainaut P, Olivier M: Impact of mutant p53 functional properties on TP53 mutation patterns and tumor phenotype: lessons from recent developments in the IARC TP53 database. Hum Mutat 2007, 28(6):622-629.

23. Thomas M, Kalita A, Labrecque S, Pim D, Banks L, Matlashewki G: Two polymorphic forms of wild type $\mathrm{p} 53$ differ biochemically and biologically. Mol Cell Biol 2001, 2:1092-1100.

24. Chosdol K, Ahuja A, Rathore A: Study of p53 codon 72 polymorphism in various etnic groups of North India. Curr Sci 2002, 82:1253-1255.

25. Vijayaraman KP, Veluchamy M, Murugesan P: p53 Exon 4 (codon 72) Polymorphism and Exon 7 (codon 249) Mutation in Breast Cancer Patients in Southern Region (Madurai) of Tamil Nadu. Asian Pacific J Cancer Prev 2012, 13:511-516.
26. Damin APS, Frazzon APG, Damin DC: Evidence for an association of TP53 codon 72 polymorphism with breast cancer risk. Cancer Detect Prev 2006, 30:523-529

27. Pharoah PD, Day NE, Caldas C: Somatic mutations in the $\mathrm{p} 53$ gene and prognosis in breast cancer: a meta-analysis. $\mathrm{Br} J$ Cancer 1999 80(12):1968-1973.

28. Thomas M, Kalita A, Labrecque S, Pim D, Banks L, Matlashewki G: Two polymorphic forms of wild type p53 differ biochemically and biologically. Mol Cell Biol 1999, 2:1092-1100

29. Kimbi GC, Kew MC, Yu MC, Arakawa K, Hodkinson J: 249ser p53 mutation in the serum of black southern African patients with hepatocellular carcinoma. J Gastroenterol Hepatol 2005, 20:1185-1190

30. Hussain SP, Amstad PR: Mutability of p53 hotspot codons to benzo(a) pyrene diol epoxide (BPDE) and the frequency of p53mutations in nontumorous human lung. Cancer Res 2001, 61(17):6350-6355.

31. Sullivan A, Syed N, Gasco M, Bergamaschi D, Trigiante G, Attard M, Farrell PJ, Smith P, Lu X, Crook T: Polymorphism in wild-type p53 modulates response to chemotherapy in vitro and in vivo. Oncogene 2004, 23:3328-3337.

32. Tommiska J, Eerola H, Heinonen M, Salonen L, Kaare M, Tallila J, Ristimäki K Von Smitten K, et al: Breast cancer patients with p53Pro72 homozygous genotype have a poorer survival. Clin Cancer Res 2005, 11:5098-5103.

33. Zhuo W, Zhang $Y$, Xiang Z, Cai $L$, Chen Z: Polymorphisms of TP53 codon 72 with breast carcinoma risk: evidence from 12226 cases and 10782 controls. J Exp Clin Cancer Res 2009, 28:115.

34. Nelson HH, Wilkjomen M, Marsit CJ, Keisey KT: TP53 mutation, allelism and survival in non-small cell lung cancer. Carcinogenesis 2005, 26:1770-1773.

35. Shen H, Liu Z, Strom SS, Spitz MR, Lee JE, Gershenwald JE, Ross MI, Mansfield PF, et al: p53 codon 72 Arg homozygotes are associated with an increased risk of cutaneous melanoma. J Invest Dermatol 2003, 121:1510-1514.

36. Costa KA, Guillo LA: TP53 codon 72 polymorphism in pigmentary phenotypes. J Biosci 2012, 37:33-39.

37. Kalemi TG, Lambropoulos AF, Gueorguiev M: The association of $\mathrm{p} 53$ mutations and p53 codon 72, Her 2 codon 655 and MTHFR C677T polymorphisms with breast cancer in Northern Greece. Cancer Let 2005, 222(1):57-65.

38. Papadakis EN, Dokianakis DN, Spandidos DA: p53 codon 72 polymorphism as a risk factor in the development of breast cancer. Mol Cell Biol Res Commun 2000, 3:389-392.

39. Alawadi S, Ghabreau L, Alsaleh M, Abdulaziz Z, Rafeek M, Akil N, Alkhalaf M: P53 gene polymorphisms and breast cancer risk in Arab women. Med Oncol 2011, 28(3):709-715.

doi:10.1186/0717-6287-47-3

Cite this article as: Ramalho et al: Assessment of changes in the brca2 and $p 53$ genes in breast invasive ductal carcinoma in northeast Brazil. Biological Research 2014 47:3.

\section{Submit your next manuscript to BioMed Central and take full advantage of:}

- Convenient online submission

- Thorough peer review

- No space constraints or color figure charges

- Immediate publication on acceptance

- Inclusion in PubMed, CAS, Scopus and Google Scholar

- Research which is freely available for redistribution 